\title{
Jaguars win critical habitat in US
}

After years of legal wrangling, the US Fish and Wildlife Service has granted jaguars protected territory.

\section{Susan Greenberg}

21 August 2012

\section{An article from Scientific American.}

Jaguars, the third-largest cats after lions and tigers—and the biggest in the Western Hemisphere—used to live here. During the 18th and 19th centuries they were spotted in Arizona, New Mexico, California and Texas. Sometimes the cats roamed as far east as North Carolina and as far north as Colorado.

As humans encroached on their territory, the endangered cats' range shifted south. Today it stretches from northern Argentina into Mexico's Sonoran Desert. But jaguars cross into the American Southwest frequently enough for some conservationists to argue that they deserve critical habitat protection. Now, after years of legal wrangling, the US Fish and Wildlife Service (FWS) has agreed. In a plan (pdf) published yesterday, the agency proposed designating 838,232 acres—an area larger than Rhode Island—as critical jaguar habitat. That means federal agencies cannot fund or authorize any activities that might "adversely modify" the earmarked land, which covers four stretches of mountain in southeastern Arizona, a section of the Peloncillo Mountains on the Arizona-New Mexico border, and a tiny piece of New Mexico's San Luis Mountains. It includes the site of a proposed copper mine in Arizona's Santa Rita Mountains, which will have to be carefully evaluated for its potential impact on jaguar habitat if the proposal is approved later this year, following a period of peer review, public comment (pdf) and economic analysis.

It is a dramatic step for the FWS, which has been dragging its feet on jaguars for years. The conservation group Center for Biological Diversity (CBD) first sued the FWS in 2003 to designate critical habitat and develop a recovery plan for the cats, which have been listed as endangered since 1997. The FWS determined that the species didn't need special protection in the US to survive, compelling the CBD to file another lawsuit in 2007. Then, in 2009, controversy erupted over the death of a jaguar known as Macho B, a male that had been captured in Arizona's Atascosa Mountains, fitted with a radio collar and released, only to be later euthanized after he was found ailing. Macho B's death added urgency to the issue, and a few weeks later a federal district court agreed with the CBD, mandating that the FWS reconsider its previous decision not to grant jaguars critical habitat. Yesterday's proposal was the result of that ruling and includes the canyon in the Atascosa Mountains where Macho B lived.

The FWS reversal should help quell a long-standing debate among conservationists, scientists, government officials, ranchers and local residents about how vital US territory is to the preservation of the species. Although the designated area represents the northernmost part of the jaguar's range, the FWS proposal argues that peripheral populations are essential to the species because their adaptation to different environmental conditions strengthens evolutionary diversity. Michael Robinson of the CBD praised the plan but wishes it went further. "These sky island mountain ranges near the border with Mexico are vital for jaguars to move into the United States," he says. "But we propose adding the Gila and Apache national forests in, respectively, New Mexico and Arizona, where roads are few and prey plentiful, in order to provide habitat for more jaguars, which could genetically bolster the population in northern Mexico."

Stealthy and mystical, jaguars (Panthera onca) lived primarily in North America until the Pleistocene epoch ended around 12,000 years ago, according to the anthropological records of the American Museum of Natural History. Since 1963 only male jaguars have been spotted in the US, and then only in south-central Arizona and southwestern New Mexico. "Counting cryptic carnivores is very, very difficult," says Howard Quigley, the executive director of the Jaguar Program of the wild cat conservation group, Panthera, and a coleader of the Jaguar Recovery Team, a group of scientists and other experts whom the FWS convened to advise the government on its decision.

Some conservationists have long argued that jaguars belong in the American Southwest. Robinson says the cats are part of Arizona's historical flora and fauna and have inherent value to the ecosystem. He also says the government essentially owes them critical habitat, because the animals' demise has come largely at the hands of the government itself. Between 1918 and 1964, records show, a federal predator extermination program killed tens of thousands of wolves and coyotes, along with an unspecified number of jaguars, probably numbering in the dozens. Furthermore, the government initially failed to list jaguars under the 1973 Endangered Species Act 
—an oversight that took more than 25 years to rectify. The American Society of Mammalogists outlined the same arguments in a 2007 resolution calling for FWS to develop a jaguar recovery plan and delineate critical habitat. With the jaguar's range steadily shrinking, the resolution said, US habitat is "vital to the long-term resilience and survival of the species, especially in response to ongoing climate change." Indeed, fringe populations are crucial to the preservation of a species, says Carlos López González, a Mexican biologist and co-leader of the Jaguar Recovery Team, who has been documenting the cats in northern Mexico since 1997, because they're part of the historical range. "Peripheral animals at the edge of a species are probably the animals that are more adaptable to climate change, global warming, drought and so on," he says.

Other prominent conservationists have argued it is a waste of time and money to focus on jaguar recovery in the . Southwest. Alan Rabinowitz, Panthera's co-founder and president,agrees that fringe populations are critical to a US species's preservation—provided they are resident or breeding populations. The closest breeding population to the Arizona border is more than 200 kilometers south in Mexico's state of Sonora. After Macho B's death, when the federal district court ordered FWS to reverse its position on critical habitat designation, Rabinowitz issued a swift rebuke on The New York Times op-ed page, calling the move "a slap in the face to good science." He wrote that the American southwest is "at best, marginal habitat for the animals," arguing that jaguar conservation efforts would be better directed at preserving "corridors" that link breeding populations with one another south of the border. He doesn't dispute that jaguars regularly cross the Mexican border into Arizona and New Mexico, but maintains they don't stay long. "There's something there that they don't like," he says. "If it was habitat they liked and could settle, why go back and forth?"

SCIENTIEIC The best hope for jaguar recovery in the Us may lie in diverting resources across the border. A M T T There's great science and money going into jaguar conservation in North America," Quigley says. "I More from Scientific American. would love to see it head south." Whereas Endangered Species Act funding may technically be used outside the US, it is rarely deployed that way. In October 2010 the US Department of Homeland Security earmarked $\$ 6.8$ million to fund conservation efforts-including just under $\$ 3$ million "to survey and monitor jaguars and their habitat in Arizona"-in an agreement with US Customs and Border Protection aimed at mitigating the impact of border security projects, such as the fence designed to deter illegal immigration. "The bad news is all the money has to be spent north of the border where there's one jaguar every three years," Quigley says. "We all realize the work needs to be done south of the border. It's horribly ironic and sad." He cites parts of the genetic corridor from Colombia to the central-southern Amazon that are critical to jaguar survival but receive no funding or attention. As the northernmost breeding center, Sonora is also key. "If we want to have jaguars in Arizona, there have to be more resources provided to Mexico," says López González, who has established incentive programs for Mexican ranchers to set photo traps for jaguars rather than kill them. Quigley says other such programs are beginning to win funding south of the border. "Our real purpose is to make sure the two core areas [Jalisco and Sonora] are preserved and there is genetic connectivity between them," he says. "If we do that right, there will be two or three jaguars that come across the border now and then." And someday, maybe more.

Nature I doi:10.1038/nature.2012.11255 